\title{
Monoclonal antibodies recognize a cell surface marker of epithelial differentiation in the rabbit reproductive tract*
}

\author{
S. A. Lampelo†, T. L. Anderson $\ddagger$ and D. W. Bullock \\ Department of Cell Biology, Baylor College of Medicine, Houston, Texas 77030, U.S.A.
}

\begin{abstract}
Summary. Monoclonal antibodies against the cell surface were produced by immunizing mice with endometrial scrapings prepared from 6-day pregnant rabbits. Spleen cells from an immune mouse were fused with myeloma cells and cultured by standard hybridoma technology methods. Hybridoma supernatants were screened for reaction with the apical epithelial surface by immunohistochemistry on frozen sections of uterus from 6-day pregnant rabbits, and positive colonies were cloned by limiting dilution. Ascites fluid was produced in mice from hybridoma clones that gave a consistent pattern of apical epithelial surface staining through 6 sub-clonings. Antibodies in the ascites fluid were tested by immunohistochemistry on frozen sections of uterus, oviduct, lung, liver and kidney from nonpregnant or 6-day pregnant rabbits. At a dilution of 1:5000, the antibodies recognized an antigen that was specific to the apical surface of luminal but not glandular epithelium of the 6-day pregnant uterus and could not be detected in the nonpregnant uterine epithelium. At higher concentrations of antibody (1:100 to $1: 1000)$, crossreaction was seen with antigens in stromal and myometrial cells of pregnant and nonpregnant uterus. At a dilution of 1:5000, the antibody also crossreacted with some components of lung, liver and kidney but without discriminating between the two reproductive states. In the oviduct, staining of the surface epithelium was specific to the pregnant state. We conclude that this monoclonal antibody has a high affinity for a luminal epithelial cell surface antigen in the reproductive tract of the pregnant rabbit and shows multiple organ reactivity with other tissues that is not affected by pregnancy. This antigen will provide a useful cell surface marker of epithelial differentiation in the progestational reproductive tract.
\end{abstract}

\section{Introduction}

It has long been recognized that the cell surface plays an important role in cellular interactions and differentiation (Gilula, 1980; Moscona, 1974; Subtelny \& Wessels, 1980; Thiery, 1984). Several techniques have been used to identify and examine the involvement of specific cell surface components in these events, including lectin binding (Milos \& Zalik, 1982; Maylie-Pfenninger \& Jamieson, 1980; Chavez \& Enders, 1982) and biochemical characterization (Pinsker \& Mintz, 1973; Magnuson \& Epstein, 1981). Recent advances in immunology have allowed the production of polyand monoclonal antibodies to identify specific markers of differentiation and investigate their functional significance. As such, stage-specific markers have been identified that characterize a wide variety of cells (Muller \& Gerisch, 1978; Hyafil et al., 1980; Knudsen et al., 1981; Yoshida \& Takeichi, 1982; Drabner \& Pokorna, 1984; Richa et al., 1985).

\footnotetext{
* Reprint requests to Dr D. W. Bullock.

tOn leave from the Department of Anatomy, University of Kuopio, Finland.

†Present address: Jones Institute for Reproductive Medicine, Division of Pregnancy Research, Eastern Virginia Medical School, Norfolk, VA 23501, U.S.A.
} 
Various techniques have been used to study differentiation of the endometrial epithelium. This epithelium is hormone-dependent, and must differentiate to provide a uterine lining that is receptive to implantation (Martin, 1980; Casimiri \& Psychoyos, 1981). Although the mechanism by which the endometrial epithelium is breached during implantation varies with species (Schlafke \& Enders, 1975; Wimsatt, 1975), this normally will not occur without appropriate hormonal conditioning (Nilsson, 1967; Potts \& Psychoyos, 1967).

The luminal epithelium of the rabbit uterus undergoes extensive differentiation before the time of implantation, and has been characterized using morphological, cytochemical, and biochemical methods. The changes described include proliferation of the luminal epithelium into numerous folds (Davies \& Hoffman, 1973, 1975), accompanied by a loss of surface negativity and alteration in glycocalyx morphology (Anderson \& Hoffman, 1984), increased affinity for certain lectins (Anderson et al., 1986), and appearance of new membrane proteins (Lampelo et al., 1985; Anderson et al., 1986). Similar progestational alterations in uterine surface negativity, glycocalyx morphology, or lectin binding have been described for rats (Hewitt et al., 1979; Murphy \& Rogers, 1981), mice (Chavez \& Anderson, 1985), sheep (Guillomot et al., 1982; Whyte \& Robson, 1984), pigs, and equids (Whyte \& Robson, 1984).

We have extended the available differentiation markers of the endometrial epithelium by producing antibodies that recognize the luminal surface of the progestational endometrium. Using endometrial scrapings from uteri of 6-day pregnant rabbits as an immunogen, we have produced monoclonal antibodies which recognize various components of the rabbit uterus. We report here the analysis of one of these antibodies, and describe its recognition of uterine and non-uterine tissues under different hormonal influences.

\section{Materials and Methods}

Immunization. Uteri were obtained from 6-day pregnant New Zealand White rabbits as described previously (Lampelo et al., 1985). Before excision the uterine vasculature was perfused in situ with about $300 \mathrm{ml}$ Tris-buffered saline (TBS; $10 \mathrm{mM}$-Tris- $\mathrm{HCl}, \mathrm{pH} 7 \cdot 3$ at $25^{\circ} \mathrm{C}, 150 \mathrm{~mm} / \mathrm{NaCl}$ ) to remove blood proteins. The uteri were excised, flushed with $10 \mathrm{ml}$ TBS to recover blastocysts, cut longitudinally and placed on ice. The endometrium was scraped off the entire luminal surface, using a microscope slide, and washed extensively with TBS under sterile conditions. Endometrial scrapings from 3-4 rabbits were suspended in $2.5 \mathrm{ml}$ TBS and drawn through a 21 -gauge needle into a syringe. BALB/c mice were injected intraperitoneally with $0.5 \mathrm{ml}$ of the endometrial suspension on 6 occasions at intervals of 3-4 weeks over a period of 5 months. Blood was withdrawn periodically and tested for the presence of antibodies by immunohistochemistry as described below. The spleen of a mouse whose serum was strongly positive for staining frozen sections of 6-day uterus was removed 3 days after the last booster and used for fusion with myeloma cells to produce hybridomas.

Monoclonal antibody production. Conventional techniques of hybridoma production were followed (Goding, 1983). Myeloma cells of the Sp2/0.Agl4 cell line were adapted to growth in Dulbecco's modified Eagle's medium (DMEM) supplemented with 10\% heat-inactivated fetal calf serum (Hazelton Dutchland, Inc., Denver, PA), 100 i.u. penicillin $/ \mathrm{ml}$ and $100 \mu \mathrm{g}$ streptomycin $/ \mathrm{ml}$ (Gibco Labs, Grand Island, NY) (complete DMEM). Myeloma cells were fused with spleen cells from an immune mouse at a ratio of 1:3 in serum-free DMEM, then resuspended in DMEM containing $0.1 \mathrm{~mm}$-hypoxanthine, $0.4 \mu \mathrm{M}$-aminopterin, $16 \mu \mathrm{M}$-thymidine, $2 \mathrm{mM}$-glutamine, $15 \%$ $(\mathrm{v} / \mathrm{v})$ fetal calf serum, and antibiotics (HAT medium), to a spleen cell concentration of $3 \times 10^{5}$ cells $/ \mathrm{ml}$.

The fusate was distributed in portions of $0.1 \mathrm{ml}$ to wells of 96 -well microtitre plates, containing $0.1 \mathrm{ml}$ of feeder cells prepared from normal spleens of non-immune mice $\left(2 \times 10^{5}\right.$ cells/well). HAT 
medium was added to the wells 3 times over the next 10 days. After 17-21 days, colony growth was dense and culture was continued in HT medium (HAT medium lacking aminopterin) for 3 days, followed thereafter by complete DMEM.

Antibody screening by immunocytochemistry. Serum from immunized mice and hybridoma media were screened by immunohistochemistry on frozen sections of rabbit uterus. Uteri were obtained from nonpregnant and 6-day pregnant rabbits as described above, flushed with TBS, cut into segments that were placed in Eppendorf sample vials (Sarstedt Inc., Princeton, NJ) and quick-frozen in hexane cooled with acetone on solid $\mathrm{CO}_{2}$ or with liquid freon, then in liquid $\mathrm{N}_{2}$. Some samples were embedded in O.C.T. compound (Tissue-Tek, Miles Scientific, Naperville, IL) before freezing. Sections $4-6 \mu \mathrm{m}$ in thickness were cut at $-20^{\circ} \mathrm{C}$ (or $-15^{\circ} \mathrm{C}$ in O.C.T.) using a Minitome cryostatic microtome (International Equipment Company, Needham Hts, MA), airdried on uncoated glass slides pre-washed with $2 \%(\mathrm{v} / \mathrm{v}) \mathrm{HCl}$ in methanol, and stored at $-20^{\circ} \mathrm{C}$ until use.

Sections were thawed briefly in phosphate-buffered saline (PBS; $10 \mathrm{~mm}$-phosphate buffer, pH $7 \cdot 3$, containing $150 \mathrm{~mm}-\mathrm{NaCl}$ ) at $37^{\circ} \mathrm{C}$ before fixation for $10 \mathrm{~min}$ in absolute methanol at room temperature. After rehydration in PBS, non-specific protein binding was blocked by incubation for $1 \mathrm{~h}$ at $37^{\circ} \mathrm{C}$ in PBS, containing $5 \%$ normal horse serum and $1 \%$ Ig-free bovine serum albumin (BSA; A7638, Sigma Chemical Company, St Louis, MO). The slides were rinsed with PBS and hybridoma medium or mouse serum diluted in PBS containing $1 \%$ BSA was placed directly over the tissue sections. Incubation proceeded at $37^{\circ} \mathrm{C}$ in a moist chamber for $\mathrm{I} \mathrm{h}$. Slides were rinsed well with PBS, and biotinylated horse anti-mouse IgG $(\mathrm{H}+\mathrm{L})$ (Vectastain kit, Vector Laboratories, Burlingame, CA), diluted as directed in PBS containing $1 \%$ Ig-free BSA, was applied to each section for incubation as described above. After rinsing well with PBS, the sections were incubated with an avidin-biotinylated peroxidase complex (ABC, Vector Laboratories) according to the manufacturer's directions. Finally, sections were washed with PBS and incubated for $10 \mathrm{~min}$ in peroxidase substrate $\left(80 \mathrm{mg}\right.$ diaminobenzidine and $13.3 \mu \mathrm{l} 30 \% \mathrm{H}_{2} \mathrm{O}_{2}$ in $100 \mathrm{ml} 0.1 \mathrm{M}$-phosphate buffer, $\mathrm{pH} 7 \cdot 3$ ). Sections were washed with PBS and mounted with gelatin-glycerol medium. In control incubations, normal mouse serum was substituted for the first antibody.

Cloning and ascites production. The selection criterion for antibody production was immunostaining of the luminal epithelial surface on frozen sections of 6-day pregnant uterus. Hybridoma cells suspensions $(0.1 \mathrm{ml})$ from selected wells were cloned by limiting dilution in 96 -well microtitre plates containing $2 \times 10^{5}$ feeder cells $(0.1 \mathrm{ml})$ per well at nominal dilutions of $4,2,1,0.5$ and 0.25 cells/well. The same selection criterion was applied and subcloning was continued for 6 or 7 generations in selected lines.

Hybridoma cells left over from selected clonings were expanded into 24-well culture plates or Petri dishes at a seeding density between $10^{4}$ and $2 \times 10^{5}$ cells $/ \mathrm{ml}$. Cells from each expansion $\left(10^{7}\right)$ were pelleted (supernatants saved for immunoassay) and resuspended by adding dropwise $5 \mathrm{ml}$ complete DMEM containing 10\% (v/v) dimethylsulphoxide (Fisher Scientific Co., Fair Lawn, NJ). Suspended cells were divided into cryogenic vials in $1 \mathrm{ml}$ aliquants $\left(2 \times 10^{6}\right.$ cells $)$. Freezing was accomplished by placing the cells for $30 \mathrm{~min}$ at room temperature, $30 \mathrm{~min}$ at $4^{\circ} \mathrm{C}, 30 \mathrm{~min}$ at $-70^{\circ} \mathrm{C}$, and finally $-120^{\circ} \mathrm{C}$ for storage.

Clones were selected for production of ascites fluid after a consistent luminal surface staining pattern was obtained in the last 3 of 6 or 7 subclonings. Male BALB/c mice were injected i.p. with $0.5 \mathrm{ml}$ pristane (2,6,10,14-tetramethylpentadecane; Aldrich Chemical Co., Milwaukee, WI), twice with a 1-week interval. At 10 days after the last treatment, the mice were injected i.p. with $5 \times 10^{5}$ hybridoma cells from cryopreserved stocks. Ascites fluid was collected by abdominal puncture after 10-14 days, and cleared by centrifugation at $10000 \mathrm{~g}$ for $10 \mathrm{~min}$.

Analysis of ascites fluid. The ascites fluid was analysed by immunoelectrophoresis in $1 \%(\mathrm{w} / \mathrm{v})$ agar in barbital buffer, ionic strength $0.075, \mathrm{pH} 8.6$. Wells were filled with ascites fluid or normal 
mouse serum (diluted 1:10 in buffer) and electrophoresis was performed at $200 \mathrm{~V}$ for $90 \mathrm{~min}$. The centre trough was filled with goat anti-mouse Ig antiserum (Cappel, Cochranville, PA) and precipitin lines were examined after diffusion for $24 \mathrm{~h}$ in a humid chamber.

Tissue from uterus, oviduct, liver, kidney and lung of nonpregnant and 6-day pregnant rabbits was frozen and sectioned as described above. Immunohistochemistry was performed using ascites fluid, diluted 1:100, 1:1000 and 1:5000 in PBS containing 1\% BSA, as the primary antibody. Normal mouse serum in place of ascites fluid was used as a control. Photomicrographs were taken with the same exposure at the magnifications indicated.

\section{Results}

\section{Monoclonal antibody production}

Distinct colonies were seen as early as I week after fusion in wells seeded with nominal dilutions of 4 cells/well. After 17-21 days, however, colonies were detected in wells seeded with 1 or less cells per well and the supernatant media were screened by immunohistochemistry on frozen sections of nonpregnant and 6-day pregnant uterus. From 200 initial hybridomas, 20 wells produced antibodies which recognized the 6-day epithelial surface, as well as other uterine components. Cells from these wells were subcloned by limiting dilution into 1920 microtitre wells. Eighty clones produced antibodies recognizing the epithelial surface and these were selected through successive subclonings for increasing specificity of epithelial surface staining in the 6-day pregnant uterus. One of these cell lines, called EBB2, was chosen for ascites production after the 6th subcloning and results from this ascites fluid are presented here. On immunoelectrophoresis, this ascites fluid gave a single precipitin line against anti-mouse $\mathrm{Ig}$ antiserum in a position corresponding to IgM (not shown).

\section{Staining pattern in the uterus}

The staining pattern of the antibody in ascites fluid at dilutions of 1:100, 1:1000 and 1:5000 on frozen sections of uterus from nonpregnant or 6-day pregnant rabbits is shown in Figs 1-6. At 1:100 dilution, intense staining of the epithelium, stroma, and myometrium was evident both in nonpregnant and pregnant rabbits (Figs 1 \& 4). At 1:1000 dilution, staining of the stroma and myometrium was less intense and the epithelial staining was markedly concentrated on the luminal epithelial surface of the 6-day pregnant compared to the nonpregnant uterus (Figs 2 \& 5). At 1:5000 dilution, the antibody stained specifically the luminal epithelial surface of the pregnant but not the nonpregnant uterus. At this dilution no glandular epithelial staining was evident and only faint staining of the nonpregnant stroma remained (Figs 3 \& 6).

The staining pattern with 1:5000-diluted ascites fluid is shown at higher magnification $(\times 220)$ in Figs 7 and 8. The absence of staining in the glandular epithelium and the specificity for the 6-day pregnant luminal surface is evident. Control sections, in which the ascites fluid was replaced by normal mouse serum, are shown in Figs 9 and 10. Results of immunostaining are shown at $\times 500$ magnification in Fig. 11. The staining is present on the outer apical surface of luminal epithelial cells, and nearly all cells appear to be stained. Where the section was cut tangential to the uterine lumen, the domed outline of the apical membranes can be seen clearly (Fig. 11).

\section{Staining of non-uterine tissues}

To assess the specificity of the antibody for the uterus, we tested the staining of EBB2 ascites fluid at 1:5000 dilution on frozen sections of liver, kidney, lung, and oviduct from 6-day pregnant and nonpregnant rabbits. There was no staining of liver parenchymal cells in tissue from pregnant 

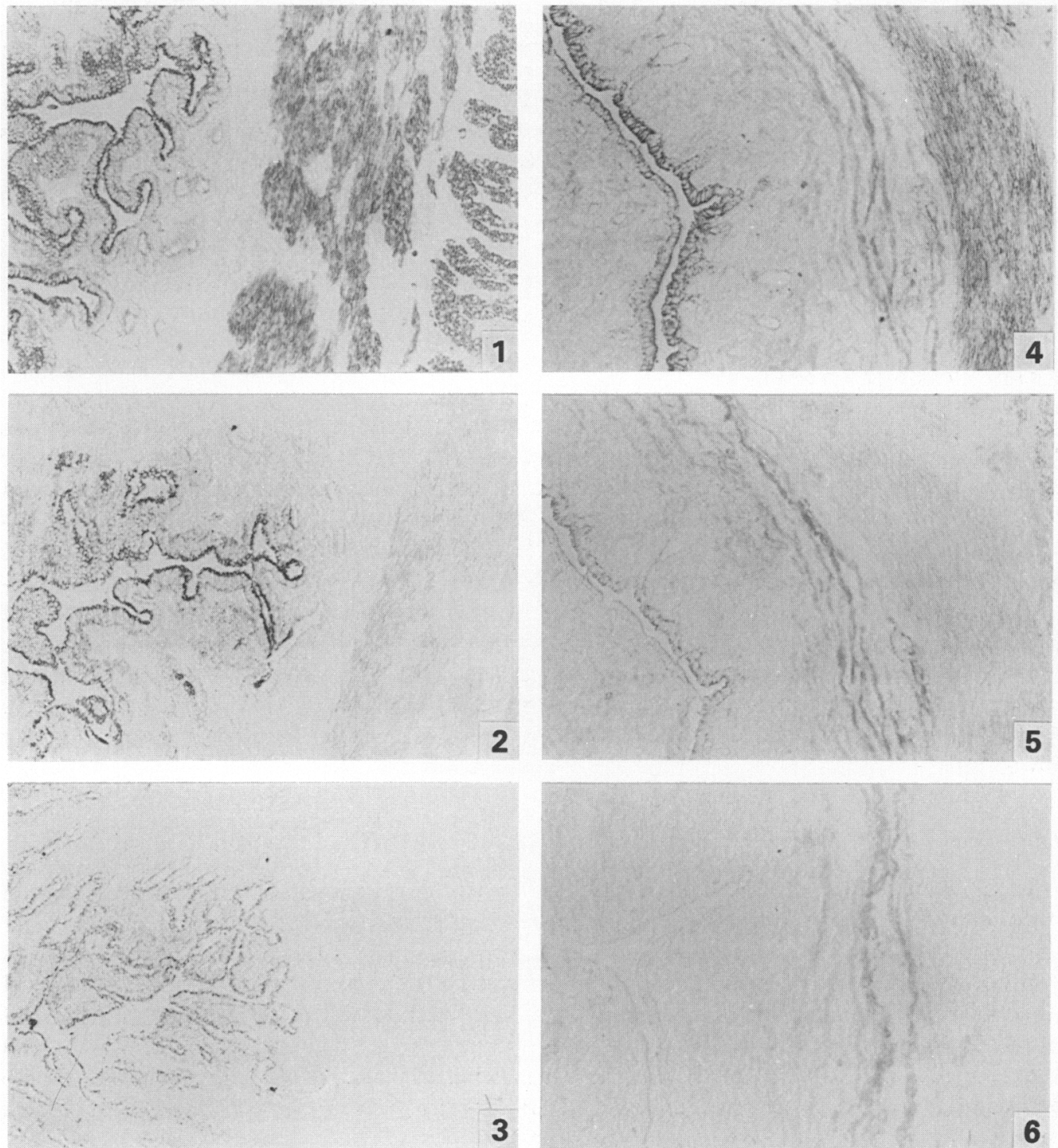

Figs 1-6. Immunohistochemistry on frozen sections of uterus from 6-day pregnant (Figs 1-3) and nonpregnant (Figs 4-6) rabbits with EBB2 ascites fluid diluted 1:100 (Figs 1 \& 4), 1:1000 (Figs $2 \& 5$ ), or 1:5000 (Figs $3 \& 6$ ). $\times 100$.

or non-pregnant rabbits. In both cases, however, the apical and basolateral plasma membranes of simple columnar epithelial cells lining major bile ducts exhibited staining, with the apical membrane being more intense (Figs 12 \& 13).

No affinity for glomerular components from the kidneys of pregnant or nonpregnant rabbits was exhibited by EBB2. However, there was moderate staining of the apical plasma membrane lining distal convoluted tubules and collecting ducts in sections of kidney from both reproductive states (Figs 14 \& 15). There was no apparent staining of membrane or cytoplasmic components of proximal tubules or vascular components in these sections. 

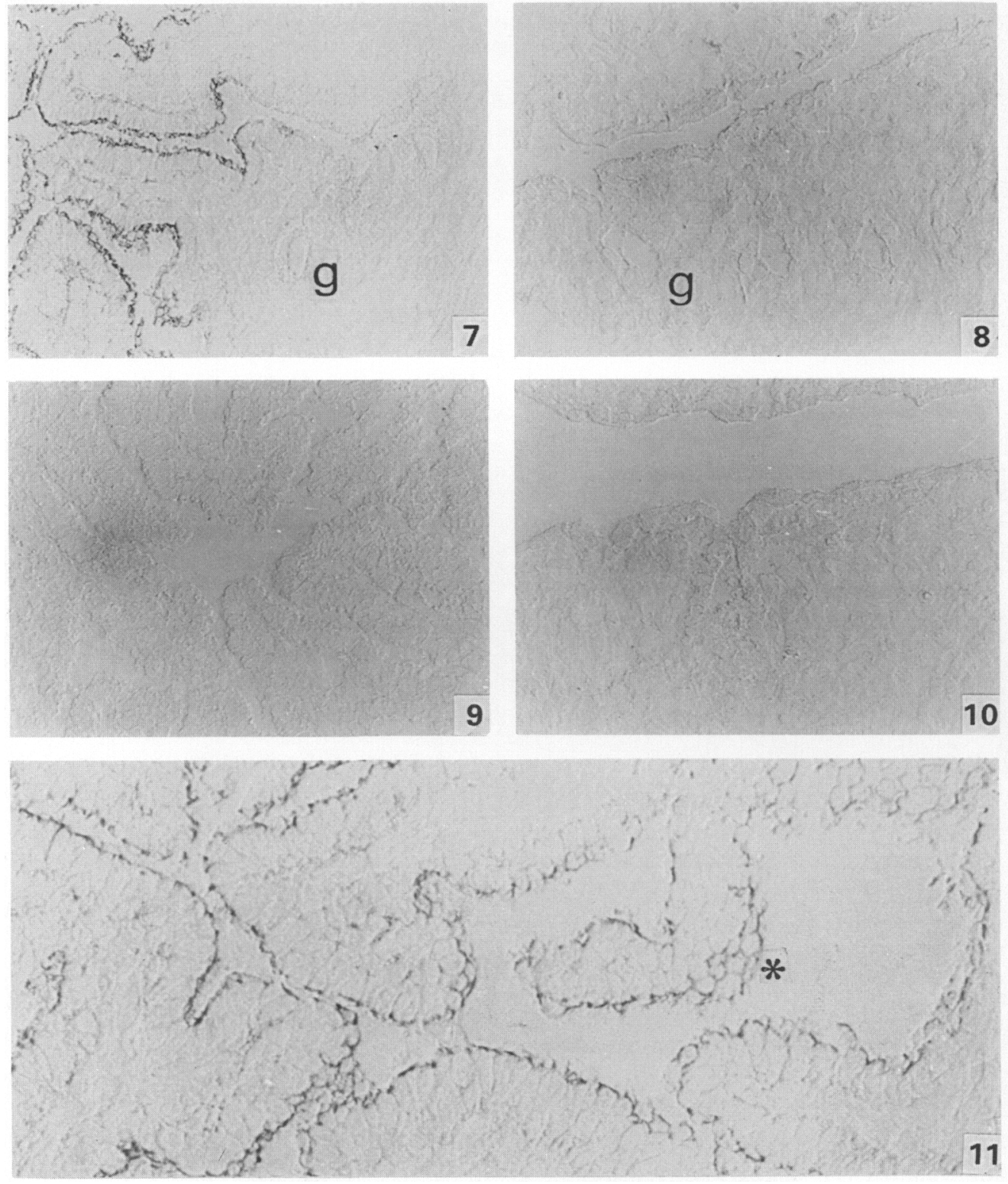

Figs 7-11. Immunohistochemistry on frozen sections of uterus from 6-day pregnant (Figs 7,9 \& 11) and nonpregnant (Figs 8 \& 10) rabbits with EBB2 ascites fluid diluted 1:5000 (Figs 7,8 \& 11) or with normal mouse serum (Figs $9 \& 10$ ). Glandular epithelium is indicated by $\mathrm{g}$ (Figs $7 \& 8$ ). A tangential section through the luminal epithelium is indicated by the asterisk (Fig. 11). Figs 7-10, $\times 220$; Fig. 11, $\times 500$.

Figs 12-19. Immunohistochemistry with EBB2 ascites fluid diluted 1:5000 on frozen sections of non-uterine tissues from 6-day pregnant (Figs 12, 14, 16, 18) and nonpregnant (Figs 13, 15, 17, 19) rabbits. Figs $12 \& 13$, liver; Figs $14 \& 15$, kidney; Figs 16 \& 17, lung; Figs 18 \& 19, oviduct. Figs 12-17, × 110; Figs $18 \& 19, \times 220$. 

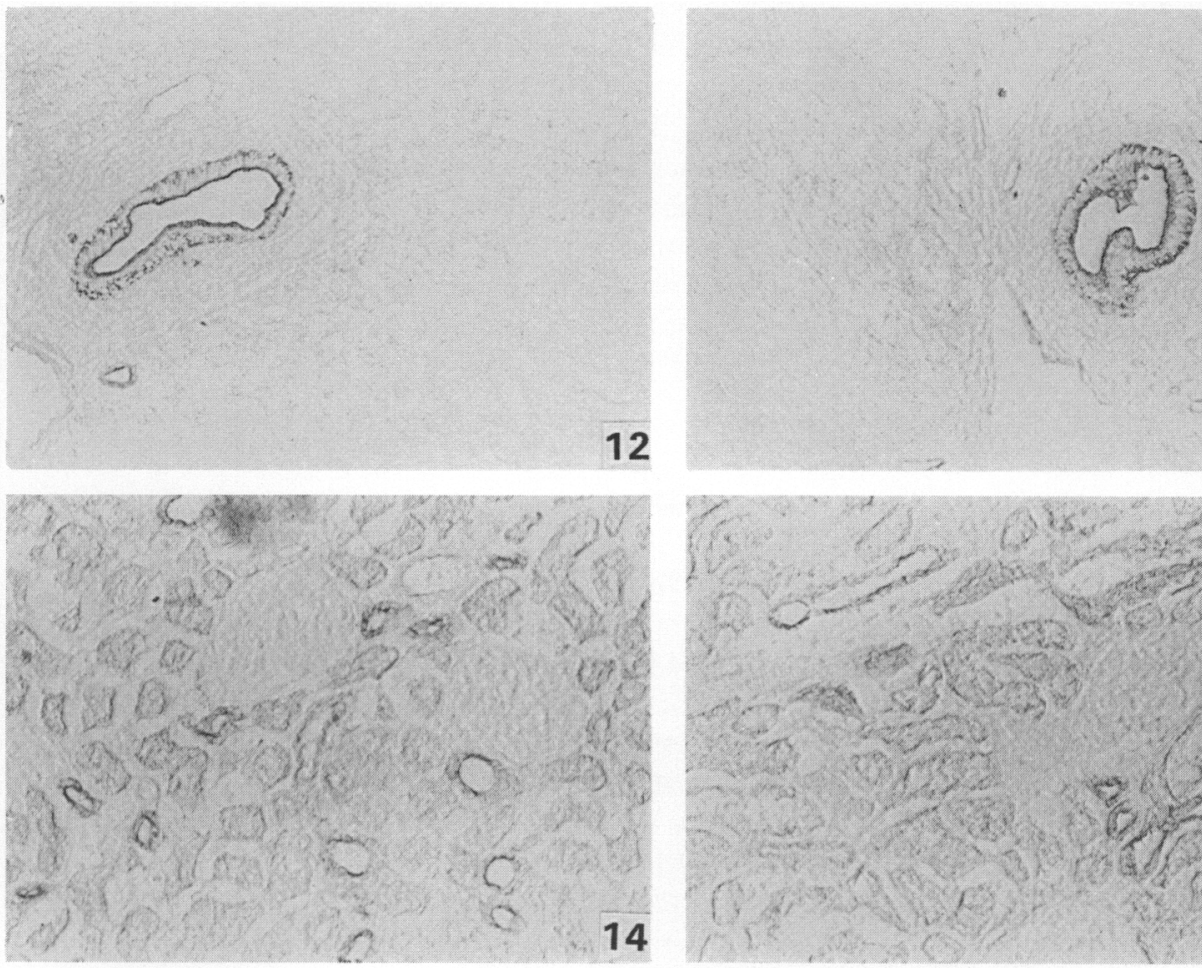

12
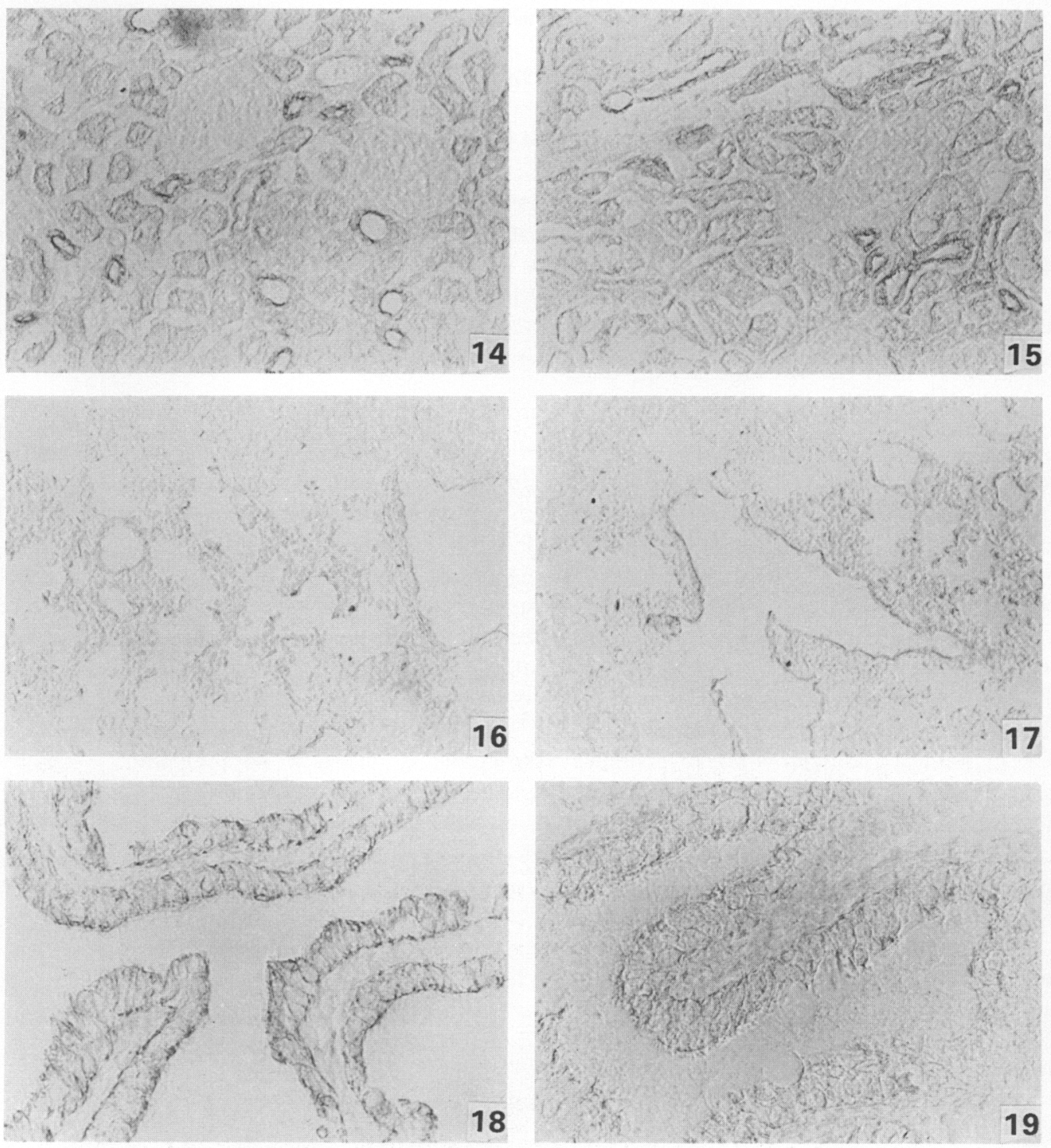
In sections of lung from pregnant or nonpregnant rabbits the antibody stained only the smooth muscle surrounding air-conducting (bronchioles) and vascular (arterioles) components (Figs 16 \& 17). No staining of the epithelial lining of either of these structures was noted, nor was staining detected in alveolar compartments or stromal cells.

Incubation of transverse sections of oviduct from nonpregnant animals with ascites fluid diluted 1:5000 revealed no staining. Similar incubation of sections of oviduct from 6-day pregnant rabbits, however, revealed staining of apical and basolateral plasma membranes of luminal epithelial cells, while no staining of stromal or myometrial elements was detected (Figs 18 \& 19).

In control incubations of each of the above tissues, where normal mouse serum was substituted for the antibody, no staining was evident, and the background was similar to that of control sections of the uterus (see Figs $9 \& 10$ ).

\section{Discussion}

In most mammals, the uterine endometrium undergoes marked epithelial proliferation and differentiation in preparation for pregnancy (Finn \& Porter, 1975). These morphological changes are regulated by oestrogen and progesterone, and the hormonal requirements have been well documented in several species (Finn, 1977). In the rabbit uterus, progesterone is a more potent mitogen than oestrogen (Lee \& Dukelow, 1972), and implantation can be sustained in ovariectomized rabbits by progesterone alone (Wu \& Allen, 1959). Few differentiation markers of the progestational epithelium are available. Two secretory proteins, uteroglobin in the rabbit (Savouret $\&$ Milgrom, 1983) and uteroferrin in the pig (Roberts \& Bazer, 1980), have been shown to be specific to the uterine epithelium and induced by progesterone. While several stage-specific changes in the uterine epithelium have been identified, no immunological probes for epithelial cell surface markers have been described.

By immunizing mice with endometrial scrapings from 6-day pregnant rabbits we have produced hybridomas secreting antibodies against a variety of uterine cells. We chose to use endometrial scrapings, rather than perform cell separation as in our earlier work (Ricketts et al., 1983), to avoid enzymic treatment and consequent degradation of membrane surface proteins (Nicolson, 1972). It is notable that such an unspecified mixture of tissue, containing many cell types and mostly undissociated cells, was successful in stimulating production of specific epithelial surface antibodies, which could be selected by appropriate screening. We have cloned a cell line that produces antibodies with a high affinity for an antigen present on the apical surface of luminal epithelial cells. At high concentrations, the antibody recognizes uterine stromal and myometrial elements but when diluted 1:5000 the antibody loses affinity for these components. We interpret this finding to mean that the antibody recognizes similar epitopes with lower affinity on non-epithelial cells in the uterus. The high-affinity antigen is not detectable on the epithelial surface in nonpregnant rabbits, and appears on the apical epithelial surface membrane in 6-day pregnant rabbits. At 1:5000 dilution, however, the antibody also recognizes the epithelial surface of the oviduct and stains different cells in the liver, kidney and lung. This staining pattern could be explained in 3 ways: the antibody is not monoclonal, the antibody recognizes the same antigen in different tissues, or the antibody shows multiple specificity for different antigens.

The evidence that the antibody is monoclonal comes from the observations that the ascites fluid was produced from a cell line that was cloned 6 times by limiting dilution at 1 or fewer cells/well; that the staining pattern in the uterus was consistent through at least the last 3 subclonings; and that a single precipitin line was obtained with immunoelectrophoresis against antimouse Ig antiserum. We therefore think it is unlikely that contamination by secondary cell lines is present.

Monoclonal antibodies show various degrees of cross-reactivity depending on the epitope which the antibody recognizes (Bundesen et al., 1980). Edwards (1981) has emphasized that monoclonal antibodies are often able to bind other antigenic determinants having enough 
structural similarity to allow recognition. The question of multiple specificity of monoclonal antibodies has been reviewed by Lane \& Koprowski (1982), who cited several examples of monoclonal antibodies binding to apparently unrelated antigens. The experimental evidence for polyfunctional antibody combining regions was examined in detail by Richards et al. (1975). Unexpected crossreaction of monoclonal antibodies is a recognized phenomenon that is rarely, if ever, observed with polyclonal antisera. Monoclonal antibodies against insulin and growth hormone stain tissues in which these genes are not expressed (Saegusa et al., 1985) and this phenomenon is known as multiple organ reactivity (Haspel et al., 1983). Because the cell type stained by the antibody in different tissues was not consistent, we believe that the cross-reactivity observed is an example of multiple organ reactivity and that the antibody may recognize different antigens.

No difference between pregnant and nonpregnant animals was seen in any of the non-reproductive tissues examined. In the uterus, however, the high-affinity antigen was specific for the luminal epithelial apical surface on Day 6 of pregnancy and did not appear in the epithelium of nonpregnant animals. The observation that the pregnancy-specific staining was found in the luminal and not the glandular epithelium agrees with the findings of Davies \& Hoffman (1973) and Conti et al. (1984) that differentiation of the rabbit endometrium involves proliferation of the luminal and not the glandular epithelium. A similar specificity for pregnancy was seen in oviducal epithelium, suggesting that hormonally regulated expression of this epitope may be a feature common to the epithelial cells of the reproductive tract. We cannot rule out at present that the same antigen is expressed constitutively in several tissues and shows changes with pregnancy only in the reproductive tract, where progesterone receptors would be expected in the cells. The pregnancy-specific staining in the oviduct and uterine epithelium suggests that this antibody will be useful for studies on a cell-surface differentiation marker of the progestational epithelium. The identity of the antigen recognized by this antibody, and its possible physiological function, are being investigated.

This work was supported in part by funds from NIH grant HD13663. We thank Dr Bonnie Dunbar for advice about monoclonal antibodies and $\mathrm{Mr}$ David Lee for excellent technical assistance.

\section{References}

Anderson, T.L. \& Hoffman, L.H. (1984) Alterations in epithelial glycocalyx of rabbit uteri during early pseudopregnancy and pregnancy, and following ovariectomy. Am. J. Anat. 171, 321-334.

Anderson, T.L., Olson, G.E. \& Hoffman, L.H. (1986) Stage-specific alterations in apical membrane glycoproteins of endometrial epithelial cells related to implantation in rabbits. Biol. Reprod. 34, 701-720.

Bundesen, P.G., Drake, R.G., Kelly, K., Worsley, I.G., Friesen, H.G. \& Sheon, A.H. (1980) Radioimmunoassay for human growth hormone using monoclonal antibodies. J. clin. Endocr. Metab. 51, 1472-1474.

Casimiri, V. \& Psychoyos, A. (1981) Embryo-endometrial relationships during implantation. In The Endometrium, pp. 63-80. Eds J. DeBrux, R. Mortel \& J. P. Gautray. Plenum Press, New York.

Chavez, D.J. \& Anderson, T.L. (1985) The glycocalyx of the mouse uterine luminal epithelium during estrus, early pregnancy, the peri-implantation period, and delayed implantation. I. Acquisition of Ricinus communis-I binding sites during pregnancy. Biol. Reprod. 32, 1135-1142.

Chavez, D.J. \& Enders, A.C. (1982) Lectin binding of mouse blastocysts: appearance of Dolichos bifloris binding sites on the trophoblast during delayed implantation and their subsequent disappearance during implantation. Biol. Reprod. 26, 545-552.

Conti, C.J., Gimenez-Conti, I., Conner, E.A., Lehman, J.M. \& Gerschenson, L.E. (1984) Estrogen and progesterone regulation of proliferation, migration and loss in different target cells of rabbit uterine epithelium. Endocrinology 114, 345-351.

Davies, J. \& Hoffman, L.H. (1973) Studies on the progestational endometrium of the rabbit: I. Light microscopy, day 0 to 13 of gonadotrophin-induced pseudopregnancy. Am. J. Anat. 137, 423-445.

Davies, J. \& Hoffman, L.H. (1975) Studies on the progestational endometrium of the rabbit: II. Electron microscopy, day 0 to 13 of gonadotrophin-induced pseudopregnancy. Am. J. Anat. 142, 335-366.

Drabner, P. \& Pokorna, Z. (1984) Differentiation antigens of mouse teratocarcinoma stem cells defined by monoclonal antibodies. Cell Differentiation 15, 109-113.

Edwards, P.A.W. (1981) Some properties and applications of monoclonal antibodies. Biochem. J. 200, 1-10.

Finn, C.A. (1977) The implantation reaction. In Biology of 
the Uterus, pp. 245-308. Ed. R. M. Wynn. Plenum Press, New York.

Finn, C.A. \& Porter, D.G. (1975) The Uterus. Elek, London.

Gilula, N.B. (1980) Membrane-Membrane Interactions. Raven Press, New York.

Goding, J.W. (1983) Monoclonal Antibodies: Principles and Practice. Academic Press, New York.

Guillomot, M., Flechon, J.-E. \& Wintenberger-Torres, S. (1982) Cytochemical studies of uterine and trophoblastic surface coats during blastocyst attachment in the ewe. J. Reprod. Fert. 65, 1-8.

Haspel, M.V., Onodera, T., Prabhakar, B.S., McClintock, P.R., Essani, K., Ray, U.R., Yagihashi, S. \& Notkins, A.L. (1983) Multiple organ reactive monoclonal antibodies. Nature, Lond. 304, 73-76.

Hewitt, K., Beer, A.E. \& Grinnell, F. (1979) Disappearance of anionic sites from the surface of the rat endometrial epithelium at the time of implantation. Biol. Reprod. 21, 691-707.

Hyafil, F., Morello, D., Babinet, C. \& Jacob, F. (1980) A cell surface glycoprotein involved in the compaction of embryonal carcinoma cells and cleavage stage embryos. Cell 21, 927-934.

Knudsen, K.A., Rao, P.E., Damsky, C.H. \& Buck, C.H. (1981) Membrane glycoproteins involved in cellsubstratum adhesion. Proc. natn. Acad. Sci. U.S.A. 78, 6071-6075.

Lane, D. \& Koprowski, H. (1982) Molecular recognition and the future of monoclonal antibodies. Nature, Lond. 296, 200-202.

Lampelo, S.A., Ricketts, A.P. \& Bullock, D.W. (1985) Purification of rabbit endometrial plasma membranes from receptive and non-receptive uteri. $J$. Reprod. Fert. 75, 475-484.

Lee, A.E. \& Dukelow, W.R. (1972) Synthesis of DNA and mitosis in rabbit uteri after oestrogen and progesterone injections, and during early pregnancy. J. Reprod. Fert. 31, 473-476.

Magnuson, T. \& Epstein, C.J. (1981) Characterization of Concanavalin A precipitated proteins from early mouse embryos: a 2-dimensional gel electrophoresis study. Devl Biol. 81, 193-199.

Martin, L. (1980) What roles are fulfilled by uterine epithelial components in implantation? Prog. Reprod. Biol. 7, 54-69.

Maylie-Pfenninger, M.-F. \& Jamieson, J.D. (1980) Development of cell surface saccharides on embryonic pancreatic cells. J. Cell Biol. 86, 96-103.

Milos, N. \& Zalik, S.E. (1982) Mechanisms of adhesion among the cells of the early chick blastoderm. Role of the $\beta$-D-galactoside-binding lectin in the adhesion of extraembryonic endoderm cells. Differentiation 21, 175-182.

Moscona, A.A. (1974) The Cell Surface in Development. John Wiley and Sons, New York.

Muller, K. \& Gerisch, G. (1978) A specific glycoprotein as the target site of adhesion blocking $\mathrm{F}_{\mathrm{ab}}$ in aggregating Dictyostelium cells. Nature, Lond. 274, 445-449.

Murphy, C.R. \& Rogers, A.W. (1981) Effects of ovarian hormones on cell membranes in the rat uterus. III. The surface carbohydrates at the apex of the luminal epithelium. Cell Biophys. 3, 305-320.
Nicolson, G.L. (1972) Topography of membrane concanavalin A sites modified by proteolysis. Nature, New Biol. 239, 187-193.

Nilsson, O. (1967) Attachment of rat and mouse blastocysts onto uterine epithelium. Int. J. Fert. 12, 5-13.

Pinsker, M.C. \& Mintz, B. (1973) Change in cell surface glycoproteins of mouse embryos before implantation. Proc. natn. Acad. Sci. U.S.A. 70, 1645-1648.

Potts, D.M. \& Psychoyos, A. (1967) L'ultrastructure des relations ovoendometriales au cours du retard experimental de nidation chez la souris. $C$. $r$. hebd. Seanc. Acad. Sci., Paris D 264, 956-958.

Richa, J., Damsky, C.H., Buck, C.A., Knowles, B.B. \& Solter, D. (1985) Cell surface glycoproteins mediate compaction, trophoblast attachment, and endoderm formation during early mouse development. Devl Biol. 108, 513-521.

Richards, F.F., Konigsberg, W.H., Rosenstein, R.W. \& Varga, J.M. (1975) On the specificity of antibodies: biochemical and biophysical evidence indicates the existence of polyfunctional antibody combining regions. Science, N.Y. 187, 130-137.

Ricketts, A.P., Hagensee, M. \& Bullock, D.W. (1983) Characterization in primary monolayer culture of separated cell types from rabbit endometrium. $J$. Reprod. Fert. 67, 151-160.

Roberts, R.M. \& Bazer, F.W. (1980) The properties, function and hormonal control of synthesis of uteroferrin, the purple protein of the pig uterus. In Steroid Induced Uterine Proteins, pp. 133-149. Ed. M. Beato. Elsevier/ North Holland, Amsterdam.

Saegusa, J., Onodera, T., Ray, U.R., Prabhakar, B.S. \& Notkins, A.L. (1985) Monoclonal antibodies that react with hormones also react with cells not containing those hormones. Endocrinology 116, 761-764.

Savouret, J.-F. \& Milgrom, E. (1983) Uteroglobin: a model for the study of progesterone action in mammals. $D N A$ 2, 99-104.

Schlafke, S. \& Enders, A.C. (1975) Cellular basis of interaction between trophoblast and uterus at implantation. Biol. Reprod. 12, 41-65.

Subtelny, S. \& Wessels, N. (1980) The Cell Surface: Mediator of Developmental Processes. Academic Press, New York.

Thiery, J.P. (1984) Mechanisms of cell migration in the vertebrate embryo. Cell Differentiation 15, $1-15$.

Whyte, A. \& Robson, T. (1984) Saccharides localized by fluorescent lectins on trophectoderm and endometrium prior to implantation in pigs, sheep and equids. Placenta 5, 533-540.

Wimsatt, W.A. (1975) Some comparative aspects of implantation. Biol. Reprod. 12, 1-40.

Wu, D.H. \& Allen, W.M. (1959) Maintenance of pregnancy in castrated rabbits by 17-alpha-hydroxyprogesterone caproate and by progesterone. Fert. Steril. 10, 439-460.

Yoshida, C. \& Takeichi, M. (1982) Teratocarcinoma cell adhesion: identification of a cell-surface protein involved in calcium-dependent cell aggregation. Cell 28, 217-224.

Received 3 April 1986 